\title{
Target Costing as a Strategic Cost Management Tool and a Survey on Its Implementation in the Turkish Furniture Industry
}

\section{Duygu CELAYİ iD a}

a Istanbul Commerce University, Department of Accounting and Auditing, Istanbul, Turkey. dcelayir@ticaret.edu.tr

\begin{tabular}{|c|c|}
\hline ARTICLE INFO & ABSTRACT \\
\hline $\begin{array}{l}\text { Keywords: } \\
\text { Strategic cost management } \\
\text { Target costing } \\
\text { Furniture Industry }\end{array}$ & $\begin{array}{l}\text { Purpose - Target Costing is implemented in product design and development phases, and hence } \\
\text { aims at cost reduction at the first stage of the life-cycle. This method is primarily intended to enable } \\
\text { enterprises to seize their desired profit margin on top of the product cost and determine a price that } \\
\text { corresponds to what customers are willing to pay. This purpose of this study is to examine the target } \\
\text { costing method and attempts to determine the extent to which it is implemented in the Turkish } \\
\text { furniture industry. }\end{array}$ \\
\hline $\begin{array}{l}\text { Received } 31 \text { January } 2020 \\
\text { Revised } 2 \text { May } 2020 \\
\text { Accepted } 5 \text { May } 2020\end{array}$ & $\begin{array}{l}\text { Design/methodology/approach - This study examines the extent to which target costing is } \\
\text { implemented at the enterprises affiliated with the Turkish Furniture Industrialists' Association and } \\
\text { the competencies related with the implementation principles of target costing. It therefore } \\
\text { determines the extent to which target costing is implemented in the Turkish furniture industry. The } \\
\text { enterprises within this study are selected from furniture industry. So Turkish Furniture } \\
\text { Industrialists' Association is selected because of reflecting furniture companies the best. }\end{array}$ \\
\hline \multirow[t]{2}{*}{$\begin{array}{l}\text { Article Classification: } \\
\text { Research Article }\end{array}$} & $\begin{array}{l}\text { Findings - Majority of the enterprises implementing target costing stated it helped address customer } \\
\text { requirements and reduce costs. They will be able to utilize the method as a significant tool for } \\
\text { competitive advantage if they follow target costing principles more diligently. Enterprises not } \\
\text { implementing it, on the other hand, are observed to be internally following the principles of the } \\
\text { method in general terms. Its implementation will be successful if the senior management assumes } \\
\text { an active role for its organization-wide ownership. }\end{array}$ \\
\hline & $\begin{array}{l}\text { Discussion - The findings obtained from the study are of great importance for the enterprises which } \\
\text { want to calculate the unit costs related to the products correctly. But, majority of the enterprises in } \\
\text { the furniture industry are observed to be employing traditional cost management systems in setting } \\
\text { the selling price. Enterprises should leave traditional methods behind and opt for the methods of } \\
\text { target costing including market research to provide products at the selling price that is desired by } \\
\text { the customers. }\end{array}$ \\
\hline
\end{tabular}

\section{Introduction}

Customer demands and expectations that rapidly change due to technological developments resulted in shorter product life-cycles and made it difficult to capitalize on economies of scale. The share of fixed costs, in particular, expanded within unit production quantities. On the other hand, customers' expectations rose steadily together with more intense competition among enterprises. This has pushed enterprises to pay more attention to product and service quality, develop strategies for competitive advantage, and determine their costs more accurately (Taylor, 2000). It has become necessary to reach quality, cost, time and design goals simultaneously and fully for enterprises to offer products at the selling price determined by the market and in the quality desired by customers while, nonetheless, obtaining a long-term competitive edge. This necessity brought along the approach toward developing products in a more market-driven manner and managing costs strategically.

Methods and models including total quality management, change engineering, flexible production systems, value engineering/analysis, target costing, product life-cycle costing, activity-based costing, kaizen costing, quality costing, environmental costing, on-time production, benchmarking, comparative analysis, and corporate scorecards emerged in the face of aforementioned developments (Can, 2004). All these strategic cost methods share one thing in common, which is the fulfillment of customer expectations in the shortest time 
period, with ultimate quality and minimum cost. Achieving this goal, however, requires product costs to be monitored and managed throughout the entire product life-cycle, while making it essential to eliminate all redundant activities in production. Target Costing is among these methods that emerged as a result of the approaches mentioned above. A product development strategy driven by customer expectations and market opportunities, target costing is a strategic profit and cost management process (Yükçü, 1999). It can be applied to the product in design and development phases in integration with other contemporary cost methods, and therefore is aimed at reducing costs at the initial stage of any given product/service. This study examines the extent to which target costing is implemented at the enterprises affiliated with the Turkish Furniture Industrialists' Association and the competencies related with the implementation principles of target costing. It therefore determines the extent to which target costing is implemented in the Turkish furniture industry.

\section{LITERATURE REVIEW}

Enterprises should offer right products at right prices and manage their costs to make profits and survive in today's global competitive market. Target costing is one of the methods developed to achieve this goal. Target costing practices guarantee the quality and reliability standards desired by the customer from a product's design phase onwards, while helping enterprises reach the profit margin they prefer (Baharudin and Jusoh, 2015). Target costing is a design-focused and price-driven profit planning tool and cost management system in which cross-functional teams work (Kaygusuz and Dokur, 2015). Target costing is the concept of price-based costing instead of cost-based pricing. A target price is the estimated price for a product or service that potential customers will be willing to pay. A target cost is the estimated long-run cost of a product or service that allows the enterprise to achieve a targeted profit. Target cost is derived by subtracting the target profit from the target price (Ramanan, 2000).

Target costing is a method that is applied in initial phases, i.e. before the production methods of a product are designed and established. When applied, all processes are carried out according to the customer, focused on production design and then extended to the entire life-cycle of the product. Target costing is intended to establish the production process that will generate the desired profit. Target costing is a management methodology aimed at driving the development process by effectively managing cross-functional relationships. It takes into account the external environment in order to obtain products that meet customer expectations. The cost of these products is consistent with business goals throughout the life cycle of the product and based on a feed-forward control (Cooper, 1994). There are various definitions of target costing. Target costing is a management tool designed to manage planning and design activities of a new product, serve as a basis for subsequent process stages, and guarantee the profits determined for a product's life-cycle. Target costing is a strategic cost management tool that links products, the market and resources, and digitizes the information regarding them. Target costing is an approach that requires the engagement of all functions regarding production (Lorino, 1995 ).

According to Cooper and Slagmulder (1997), target costing is an approach that determines the selling price and life-cycle costs according to desired profitability for the useful life of a product/service to be produced as per a certain level of quality and function. Everaert et al. (2006) defined target costing as a process during which product costs are determined in initial phases of new product development that enables such target costs to be reached in the development process of a new product.

Schmelze and Geiger (1996) described target costing as an effective and proven method reducing product costs throughout the life-cycle of a product without increasing the time period during which a product is designed and developed and decreasing quality or functionality. Tanaka (1997) refers to target costing as to a concept that has two forms of manifestation. The duality of target costing is taken from the producer's and from the client's point of view: first and foremost are the costs that it incurs the manufacturer, such as planning, designing, developing, manufacturing and selling costs; secondly are the costs borne by the buyer, such as maintenance, exploiting and elimination cost. Within this scope, target costing is an approach aimed at reducing product life-cycle costs of new products through examining all ideas related with cost reduction in product planning, research and development processes provided that quality, reliability and other expectations of customers are addressed (Kato, 1993). Target costing aims at cost management in planning and design phases of products/services, while helping managers make more reasonable decisions in development phase and encouraging employees to adopt a long-term thinking. It is a cost management tool that is used to 
reduce costs with the assistance of production, engineering, R\&D, marketing and accounting departments (Sakurai, 1990).

Target costing is used as a tool to reduce the total life-cycle costs of a product by focusing on design and planning phases (Kaplan and Atkinson, 1998). It initiates cost management in early phases of product development, actively extends through the entire value chain and applies cost management throughout the life-cycle of a product. According to Hansen and Mowen (1999), target costing is an interactive process that is repeated until a defined target is reached or until it is determined that a target is impossible to reach. Adopting this approach, they argue that the most reliable way to determine a price is to start out with one that the market is willing to pay. Seidenschwarz (1993) divides existing definitions under three categories. Definitions of target costing are categorized as

- market-driven;

- engineering-driven;

- and functionality-driven.

Target costing is a strategic cost management tool that reduces product costs in planning and design phases. This is achieved through focusing on the integrated efforts of all relevant functions, such as marketing, engineering, production and accounting, within an enterprise. This cost reduction process is continuously applied in initial phases of production (Sakurai, 1996). Target costing is primarily intended to enable enterprises to seize their desired profit margin on top of the product cost and determine a price that corresponds to what customers are willing to pay. Target cost is determined by the market since product costs are dictated upon by customers. It is possible to lay down the key assumptions related with the method as follows (Hacırüstemoğlu and Şakrak, 2002):

- The selling price of the products is set by the target market.

- The profit margin intended to be reached is subtracted from the selling price.

- The remaining amount is determined as the target cost which has to be incurred if the product is produced.

The target cost shows the difference between the target price and determined profit. In target costing, product quality should not be overlooked and imbalances between price and quality prevented through thinking with a focus on the customer (Kalkanc1, 2008).

Target costing concept implies an integrated mechanism where we can find the three mentioned orientations, as it follows (Dimi and Simona, 2014):

- the basic characteristic of the target costing consists in its clear orientation towards the market, the estimation of the price being made taking into account the estimated price that can be obtained in future by selling the product on the market;

- establishing the target costing is not made by only taking into account the estimated price accepted on the market, its objective being that of analysing the characteristics of the new product planning and designing phases but also by using target cost to track and control the actual incurred costs;

- any resource economy must be made respecting the product's functionality established by the client, otherwise any cost reduction will have a negative impact: the consumer may refuse the product.

All the stakeholders within the value chain are expected to be involved in target costing during cost reduction. Focus should be placed on eliminating waste, deficiencies and errors that may occur during the product life-cycle. Moreover, stakeholders should be careful about costs related with the rectification of errors, and re-use or disposal of the deficient product (Helms, Ettkin, Baxter and Gordon, 2005).

\subsection{The Aim of Target Costing}

Competition pushes enterprises to produce products or services in the quality and with the functions aligned with customer expectations and demands, whilst necessitating sales thereof at the price determined by the market (Castellano and Young, 2003). The knowledge on costs in modern production environments cannot be produced with the speed, benefits and accuracy required by the fierce competition through traditional cost 
methods. It is necessary to develop methods, systems and models that can produce more accurate, faster, more useful and reliable information, and the need for target costing rises every passing day.

The core objective of target costing is to reduce the costs of new products, which will address customers' requirements for quality, reliability and functionality, throughout their life-cycles (Dekker and Smidt, 2003, Kalkanc1, 2008). Target costing, while ensuring the continuity of optimum quality, reduces total costs. Within this scope, target costing ensures optimal balance between quality, functionality and cost. Most production enterprises employ target costing for the purposes of strategic profit planning (Sakurai, 1990). Other objectives of target costing could be summarized as follows (Karcioğlu, 2000):

- Ensuring alignment of enterprises, costs in particular, with the market

- Providing cost management support for a product in initial phases and hence ensuring that product costs can be managed even in design phase

- Helping enterprises expand their existing market share

- Maximizing profit margins, and ensuring continuous control over cost targets for a dynamic cost management.

- Helping the corporate strategy take shape according to market requirements.

Also, key features of target costing can be listed as follows (CFI, 2019):

- The price of the product is determined by market conditions. The company is a price taker rather than a price maker.

- The minimum required profit margin is already included in the target selling price.

- It is part of management's strategy to focus on cost reduction and effective cost management.

- Product design, specifications, and customer expectations are already built-in while formulating the total selling price.

- The difference between the current cost and the target cost is the "cost reduction," which management wants to achieve.

- A team is formed to integrate activities such as designing, purchasing, manufacturing, marketing, etc., to find and achieve the target cost.

\subsection{Key Principles of Target Costing and the Target Costing Process}

Target costing is a market-driven costing system. It is established based on the offers of the competition and customers' requirements. Target costing is a system for profit planning and cost methods. It is a functional system at the heart of which price setting, customer centricity and design lies (Ansari and Bell, 1997). Cost management is initiated in product development phase and applied throughout the product life-cycle in a manner to cover the entire value chain. Target costing can best be described as a systematic process of cost management and profit planning. The six key principles of target costing are (Swenson et al. 2003):

1. Costing per Price: In target costing, target selling price is determined first. The target selling price stands for the amount consumers consider paying for the products produced by an enterprise. Target profit margin is subtracted from this price to determine the target cost. Costing per price is composed of two key subprinciples (Ansari and Bell, 1997). Product and profit margin are determined by market prices. The process should be regularly analyzed for the enterprise to opt for products with consistent and reliable profit margins. Target costing is based on knowledge and analyses of active competition. It is important to have an understanding of how market prices have been set.

2. Focus on customers: Target costing is a process under the impact of the market, and customers' opinion is continuously taken into account. Customer requirements for quality, cost, and time are simultaneously incorporated in product and process decisions and guide cost analysis. The value (to the customer) of any features and functionality built into the product must be greater than the cost of providing those features and functionality.

What needs to be considered in product design is elimination of those features that will add on the product cost but nevertheless fail to bring in further value for the consumer. 
3. Focus on design: Target costing manages costs before they are incurred. Although most costs arise in production, many of them are caused by issues related with design. Target costing, though, focuses on a design that enables cost control/reduction throughout the life-cycle of a product (Ansari and Bell, 1997). Cost control is emphasized at the product and process design stage. Therefore, engineering changes must occur before production begins, resulting in lower costs and reduced "time-to-market" for new products.

4. Cross-functional involvement: One of the key aspects of target costing is the adoption of a team approach to achieve the target cost. Team members represent a broad group of people including producers, engineers, designers, R\&D experts, marketing specialists, and suppliers (Sakurai, 1989). Cross-functional product and process teams are responsible for the entire product from initial concept through final production.

5. Value-chain involvement: Target costing deals with all the stakeholders of a value chain, from vendors and distributors to customer services. The method is built on long-standing, beneficial relationships to be established with the aforementioned. This is how it extends cost reduction efforts across the entire value chain, by partnering with all other parties outside an enterprise (Hacırüstemoğlu and Şakrak, 2002).

6. A life-cycle orientation: The method is primarily aimed at minimizing product life-cycle costs on the side of both producers and customers. Total life-cycle costs are minimized for both the producer and the customer. Life-cycle costs include purchase price, operating costs, maintenance, and distribution costs.

There are certain requirements for the effective implementation of those principles (Bahşi and Can, 2001):

- Involving suppliers in product development process;

- Designing products and processes simultaneously;

- Giving a direction to all cost reduction efforts according to customers' expectations;

- Simplification of design and measurement thereof;

- Establishing teams composed of representatives from different functions in activities related with target costing; and

- Establishing an organizational structure and culture open to continuous change and improvement.

Target costing process: The target costing process can be summarized in three main stages which are linked to the development cycle of the product (Sakurai, 1989):

1-Setting the allowable cost that relates to the planning stage (corporate planning) and initial design of the product;

2-Setting and achieving the target cost that is linked to the detailed design of the product and to the production

3-Plan (industrialization and manufacturing preparation); target cost achievement in the product implementation phase using standard cost, the kaizen costing technique or value analysis.

The first two stages make up the design phase of target costing, while the third constitutes the operational phase. The first stage of the target costing process is aimed at determining the allowable cost and is linked to strategic planning - identifying specific markets, consumers and products that the company intends to develop - and to the initial design of the product. This cost is determined by calculating the difference between the price, set according to the logic outlined above, and expected profit and it constitutes the largest value of resources that can be used by the company to obtain the product.

\subsection{The Success of Target Costing}

The following requirements should be addressed to achieve desired results with target costing while properly following up its implementation and carrying out relevant stages (Bozdemir and Orhan, 2011).

Supplier participation: Many large enterprises procure the parts, by-products, semi-finished products, raw materials and materials used in production from suppliers. Therefore, suppliers should be considered strategic partners and involved in the process of target costing. It is strategically important to establish good relations with suppliers and work with fewer suppliers, if possible, because input costs make a direct impact on product 
costs. Within this framework, it would be useful for enterprises to implement supply chain management principles (Yalçın, 2005).

Simultaneous design: Products have to be designed simultaneously. Rather than researching whether a product can be produced by designing of its features first, production processes should be made ready simultaneously with the product design, which would prevent waste of time.

Customers' expectations: The price is determined as per customers' expectations and the amount they are willing to pay in target costing. Therefore, it is important to take customers into account during cost reduction efforts (Coşkun, 2002-2003). Including customers in the design team and exploring their opinion through market research or systematic and various methods will enable the design to be developed in the light of such opinions and negative situations to be identified beforehand and prevented.

Design simplicity and measurement: For a successful target costing system, it is a pre-requisite to simplify designs as much as possible. The number of parts in a product should be minimized to prevent complications (Altınbay, 2006).

Establishing a target costing team: An enterprise should establish a good target costing team and include employees from various functions, such as product development, product engineering, procurement, sales, and cost control.

Organizational culture: The organizational culture should be open to continuous change and development. Enterprises with effective target costing systems always renew themselves, without having to compromise on their core values.

Use of other techniques: Use of certain techniques and practices may prove necessary in target costing. The success of target costing will depend on the extent to which other techniques and methods have been implemented. Methods that are considered key components of target costing include value engineering, cost tables, value chain analysis, disassembly analysis, quality function deployment, balanced scorecard and inspection analysis.

\section{DATA AND SAMPLING:}

Changing economic and social conditions of today have pushed enterprises in the furniture industry to carry out production and sales activities in the face of tough competition. Therefore, they have started placing great importance on cost management to maintain their presence in national and international markets, preserve their competitive power, and reach their cost, time, quality and technology targets in a simultaneous manner and at an optimal level. Within this scope, target costing is considered a significant costing tool. Target costing, although it has been touched upon by a series of studies in Turkey since 1990s, lacks comprehensive examination and discussion when it comes to its implementation. This study examines the extent to which increasingly important target costing, which is used by many enterprises around the globe as a strategic cost management process and profit planning tool, is implemented in one of the driving industries in Turkey, i.e. the furniture industry. This study primarily intends to identify enterprises implementing target costing and determine how they comply with the principles of implementation for target costing in processes such as cost and price setting, customer analysis and cost reduction efforts. It also aims to lie down the reasons as to why some enterprises do not implement target costing and to measure its usability in the future.

\section{METHOD:}

\subsection{Data Collection Method and Analysis Used}

Survey forms based on primary sources were used as the data collection tool for the purpose of this study. Questions in the survey form, which was prepared to achieve the intended purpose of this study, were determined taking the literature in Turkey and the world and former surveys conducted in different industries into account.

\subsection{Scope of the Research and Sampling}

The population is composed of 39 leading furniture firms in Turkey affiliated with the Turkish Furniture Industrialists' Association. The main reason for selecting the members of the Turkish Furniture Industrialists' 
Association is their level of institutionalization in the industry and strong organizational structure, which is required for implementation of sophisticated methods such as target costing. Information derived will therefore be more consistent and reliable. As part of the survey, information was collected by e-mail and oneon-one interviews with some enterprises. Only 14, though, replied to the questions in the survey.

\section{ANALYSIS AND RESULTS}

Respondents were asked questions on key principles and features of target costing, as well as the level of its implementation at their own enterprises. In addition to evaluating how the method is implemented at enterprises, questions that were associated with the features of the method were aimed at examining how closely they stood to the principles of the method in practice. Respondents' positions within those enterprises are outlined in Table 1.

Table 1: Respondents' Positions at Their Own Enterprises

\begin{tabular}{|l|l|l|}
\hline Position & N (Number) & Percentage (\%) \\
\hline Senior Executive & 4 & 28.6 \\
\hline Officer in Charge of Production Department & 4 & 28.6 \\
\hline Accounting, Finance & 2 & 14.3 \\
\hline Factory responsible & 2 & 14.3 \\
\hline Department officer & 2 & 14.3 \\
\hline TOTAL & 14 & 100.0 \\
\hline
\end{tabular}

Looking at respondents' positions, four are senior executives $(28.6 \%)$, four in charge of the production department $(28.6 \%)$, two in charge of accounting and finance $(14.3 \%)$, two in charge of the factory $(14.3 \%)$, and two in charge of their relevant departments (\%14.3). Operating periods of enterprises in the furniture industry are outlined in Table 2:

Table 2: Enterprise Operating Period in the Furniture Industry

\begin{tabular}{|l|l|l|}
\hline Years & N (Number) & Percentage (\%) \\
\hline Less than 3 years & 0 & 0 \\
\hline 3-5 years & 0 & 0 \\
\hline 5-10 years & 3 & 21.4 \\
\hline 10-20 years & 7 & 50.0 \\
\hline 20 years and above & 4 & 28.6 \\
\hline TOTAL & 14 & 100.0 \\
\hline
\end{tabular}

Looking at enterprises' operating period in the industry, 21.4\% have been in the industry for $5-10$ years, 50\% for $10-20$ years, and $28.6 \%$ for more than 20 years. Figures reveal that the majority of the enterprises that responded to the survey have sufficient experience in the industry in which they operate. Table 3 outlines the target markets of the enterprises:

Table 3: Enterprise Target Market

\begin{tabular}{|l|l|l|}
\hline Target Market & N (Number) & Percentage (\%) \\
\hline Domestic & 5 & 35.7 \\
\hline International & 0 & 0 \\
\hline Both domestic and international & 9 & 64.3 \\
\hline TOTAL & 14 & 100.0 \\
\hline
\end{tabular}

A look into enterprises' target markets shows that $35.7 \%$ operate only in the domestic market, whereas $64.3 \%$ operate both in domestic and international markets. Tough competition in domestic and international markets pushes enterprises to be more careful about costs. Therefore, one could say that enterprises with operations both in domestic and international markets should pay more attention to costs. The following table summarizes the factors enterprises think are important for competitive advantage. 
Table 4: Important Factors for Competitive Advantage

\begin{tabular}{|l|l|l|l|l|l|l|l|l|l|l|l|}
\hline \multirow{2}{*}{ Factors } & \multicolumn{3}{|l}{ Most Important } & $\begin{array}{l}\text { Very } \\
\text { Important }\end{array}$ & \multicolumn{2}{l|}{ Important } & \multicolumn{2}{l|}{$\begin{array}{l}\text { Less } \\
\text { Important }\end{array}$} & \multicolumn{2}{l|}{ Unimportant } \\
\cline { 2 - 14 } & $\mathrm{N}$ & $\%$ & $\mathrm{~N}$ & $\%$ & $\mathrm{~N}$ & $\%$ & $\mathrm{~N}$ & $\%$ & $\mathrm{~N}$ & $\%$ \\
\hline Production & 2 & 14.3 & 12 & 85.7 & 0 & 0 & 0 & 0 & 0 & 0 \\
\hline Costs & 14 & 100 & 0 & 0 & 0 & 0 & 0 & 0 & 0 & 0 \\
\hline Quality & 8 & 57.1 & 6 & 42.9 & 0 & 0 & 0 & 0 & 0 & 0 \\
\hline Speed & 1 & 7.1 & 8 & 57.1 & 5 & 35.7 & 0 & 0 & 0 & 0 \\
\hline Design & 4 & 28.6 & 6 & 42.9 & 4 & 28.6 & 0 & 0 & 0 & 0 \\
\hline
\end{tabular}

Cost was observed to be the most important factor with a percentile of $100 \%$. Cost is important to gain competitive advantage for enterprises in the furniture industry. However, competitive advantage is not only achieved with cost looking at today's conditions. Enterprises should place importance on other factors, as well. The second most important factor is quality, according to the table. This has shown that enterprises pay attention to the quality of the products they offer to consumers.

The third important factor is design. This emphasis on design creates a positive impact in terms of the level of target costing implementation. One of the key elements of target costing is conducting market analysis. Respondents were asked whether they conduct market analysis, as shown in the results provided in the following table.

Table 5: Level of Market Analysis Implementation

\begin{tabular}{|l|l|l|}
\hline Market Analysis & N & \% \\
\hline Sufficient & 9 & 64.3 \\
\hline Partially & 4 & 28.6 \\
\hline Never conduct & 1 & 7.1 \\
\hline Total & 14 & 100.0 \\
\hline
\end{tabular}

Nine enterprises $(64.3 \%)$ said they conducted sufficient analyses, four said they conducted partial analyses $(28.6 \%)$, and one said they never conduct analyses $(7.1 \%)$, as per the evaluation on whether enterprises conduct market/product analyses before producing a new product. With market analysis, enterprises identify customers' requests and needs and shape production activities accordingly, as part of target costing. 64.3\% of the respondents as cited above are anticipated to be seeing its positive reflection on the level of target costing implementation.

Enterprises were also asked about the factors they researched in market analyses, as summarized in Table 6.

Table 6: Factors Researched in Market Analysis Before Production

\begin{tabular}{|l|l|l|l|l|l|l|l|l|l|l|l|l|}
\hline \multirow{2}{*}{ Factors } & \multicolumn{2}{|l|}{ Always } & \multicolumn{2}{l|}{ Usually } & \multicolumn{2}{l|}{ Sometimes } & \multicolumn{2}{|l|}{ Rarely } & \multicolumn{2}{l|}{ Never } \\
\cline { 2 - 14 } & $\mathrm{N}$ & $\%$ & $\mathrm{~N}$ & $\%$ & $\mathrm{~N}$ & $\%$ & $\mathrm{~N}$ & $\%$ & $\mathrm{~N}$ & $\%$ \\
\hline $\begin{array}{l}\text { Customers' product-related } \\
\text { preferences and expectations }\end{array}$ & 8 & 57.1 & 4 & 28.6 & 2 & 14.3 & 0 & 0 & 0 & 0 \\
\hline $\begin{array}{l}\text { Price customer anticipates for } \\
\text { the product }\end{array}$ & 7 & 50.0 & 4 & 28.6 & 2 & 14.3 & 1 & 7.1 & 0 & 0 \\
\hline $\begin{array}{l}\text { Potential sales volume of the } \\
\text { product }\end{array}$ & 2 & 14.3 & 6 & 42.9 & 6 & 42.9 & 0 & 0 & 0 & 0 \\
\hline $\begin{array}{l}\text { Knowledge on competitors' } \\
\text { products }\end{array}$ & 1 & 7.1 & 3 & 21.4 & 8 & 57.1 & 2 & 14.3 & 0 & 0 \\
\hline
\end{tabular}

According to Table 6, customer preferences and expectations is the first factor enterprises seek to understand in market analysis. The second important factor is the price customers anticipate for a given product. This shows that enterprises make sure to consider customer preferences and expectations and the price anticipated by the consumer, both of which are key elements for target costing. This situation is also in a position to support target costing. Cost estimation is another important factor in target costing. Following are the replies to the question "In which stages do you make cost estimates while developing a new product?" 
Table 7: Stages in which cost estimates are made

\begin{tabular}{|l|l|l|l|l|l|l|}
\hline \multirow{2}{*}{ Stages } & Yes & \multicolumn{2}{l|}{ Do not know } & No \\
\cline { 2 - 7 } & $\mathbf{N}$ & $\mathbf{0}$ & $\mathbf{N}$ & $\mathbf{\%}$ & $\mathbf{N}$ & $\mathbf{\%}$ \\
\hline After a new product idea is conceived & 8 & 57.1 & 5 & 35.7 & 1 & 7.1 \\
\hline During new product design & 11 & 78.6 & 3 & 21.4 & 0 & 0 \\
\hline After production for the new product starts & 12 & 85.7 & 0 & 0 & 2 & 14.3 \\
\hline After production is completed & 12 & 85.7 & 0 & 0 & 2 & 14.3 \\
\hline We do not make cost estimates in any stage. & 2 & 14.3 & 1 & 7.1 & 11 & 78.6 \\
\hline
\end{tabular}

$57.1 \%$ of enterprises stated they make cost estimates after the idea of a new product is conceived. $78.6 \%$ stated they make cost estimates during new product design, while $85.7 \%$ said they make cost estimates after production for the new product starts. $14.3 \%$ do not make cost estimates in any stage. As for target costing, the cost of a product is determined in product design and development. $78.6 \%$ shows that the majority comply with this principle. Respondents were asked whether they undertake any cost reduction efforts for new and existing products at their enterprises. Seven said they exert sufficient level of efforts (50\%), six said their efforts were partial $(42.9 \%)$ and one said they do not undertake any efforts $(7.1 \%)$. When asked the stage in which cost reduction efforts were undertaken, respondents replied as follows.

Table 8: Stages in which Cost Reduction Efforts are Undertaken

\begin{tabular}{|l|l|l|}
\hline Stages & $\mathbf{N}$ & $\mathbf{\%}$ \\
\hline In design, before production & 1 & 7.1 \\
\hline During production & 6 & 42.9 \\
\hline After production is completed & 0 & 0 \\
\hline In each phase of product life-cycle & 7 & 50.0 \\
\hline Total & 14 & 100 \\
\hline
\end{tabular}

$42.9 \%$ stated they carry out cost reduction activities at the stage of production, while $50 \%$ undertake cost reduction efforts in each phase of the product life-cycle. $7.1 \%$ of enterprises carry out cost reduction activities at the design stage before production. Cost reduction activities should be conducted in every phase of product life-cycle for effective implementation of target costing. However, enterprises undertaking such efforts in production should try to reduce this rate. As for competitive advantage, the product may lose some of its competitive edge due to high market price, considering the fact that cost reduction efforts made in production sometimes can never be interfered with.

Respondents were asked on the departments in charge of cost reduction activities, and the results are outlined in Table 9.

Table 9: Departments in Charge of Cost Reduction Activities

\begin{tabular}{|l|l|l|l|l|l|l|}
\hline \multirow{2}{*}{ Departments } & \multicolumn{2}{l|}{$\begin{array}{l}\text { Sufficiently } \\
\text { Responsible }\end{array}$} & \multicolumn{2}{l|}{$\begin{array}{l}\text { Partially } \\
\text { Responsible }\end{array}$} & \multicolumn{2}{l|}{ Not Responsible } \\
\cline { 2 - 8 } & N & $\%$ & N & $\%$ & N & $\%$ \\
\hline Supply & 10 & 71.4 & 4 & 28.6 & 0 & 0 \\
\hline Production & 11 & 78.6 & 3 & 21.4 & 0 & 0 \\
\hline Design and production engineering & 6 & 42.9 & 7 & 50.0 & 1 & 7.1 \\
\hline Accounting & 8 & 57.1 & 4 & 28.6 & 2 & 14.3 \\
\hline
\end{tabular}

Production departments assume the greatest responsibility in cost reduction activities with $78.6 \%$, as revealed by the table above. This is followed by supply and accounting departments with $71.4 \%$ and $57.1 \%$ respectively. However, all functions are recommended to take part in cost reduction activities in target costing. More responsibility should be assigned to design and production engineering departments. It is important to include the members within a value chain in new product development processes and make sure they work towards a share goal. Suppliers are one of them. Respondents were asked whether suppliers were included in new product development processes, and the results are provided in Table 10. 
Table 10: Suppliers' Level of Participation in New Product Development

\begin{tabular}{|l|l|l|}
\hline Participation & N & $\mathbf{\%}$ \\
\hline Sufficiently & 5 & 35.7 \\
\hline Partially & 9 & 64.3 \\
\hline We do not include them & 0 & 0 \\
\hline
\end{tabular}

According to Table 10, 35.7\% said suppliers' participation is sufficient and 64.3 said it is partial. As a member of the value chain, suppliers should be involved in product development processes in target costing. It is therefore essential for enterprises to give suppliers more chance to take part in those processes. Regarding dealers, who are also among the members of the value chain, respondents were asked whether they interact with dealers before product design. Results are shown in Table 11.

Table 11: Level of Interaction with Dealers

\begin{tabular}{|l|l|l|}
\hline Dealers & N & \% \\
\hline Sufficiently & 8 & 57.1 \\
\hline Partially & 5 & 35.7 \\
\hline We do not interact & 1 & 7.1 \\
\hline Total & 14 & 100.0 \\
\hline
\end{tabular}

Respondents were asked whether they interact with dealers before development of a new product. Eight said they did sufficiently (57.1\%), five partially (35.7\%), and one stated they did not interact (7.1\%). Dealers are also part of the value chain, and it would therefore be useful to take their opinion into account especially before product design to help shape the design. It would serve as a guiding light to have a better understanding of customers' needs.

Target costing is based on the idea that the price is determined by the market. Thus, respondents were asked how they set the selling price of a new product.

Table 12: Setting Selling Price

\begin{tabular}{|l|l|l|}
\hline Way of Setting Price & N (Number) & Percentage (\%) \\
\hline Adding a certain profit margin on costs & 5 & 35.7 \\
\hline According to the price set by competition & 2 & 14.3 \\
\hline Through market research & 5 & 35.7 \\
\hline Looking at the price of similar products & 2 & 14.3 \\
\hline TOTAL & 14 & 100.0 \\
\hline
\end{tabular}

When asked how they set the selling price of a new product, $35.7 \%$ of enterprises said they added a certain profit margin on costs, $14.3 \%$ determined the price according to the one set by competition, $35.7 \%$ set through market research, and $14.3 \%$ looked into the price of similar products. Setting the price by adding a certain profit margin on costs is a traditional method (cost + profit). $35.7 \%$ of enterprises continue to follow this method. An equal number of enterprises, on the other hand, stated they set the selling price through market research, which shows that they comply with the core principle of target costing, i.e. "the price is determined in the market." Respondents were also asked if they implemented target costing at their enterprises. Results are provided in Table 13.

Table 13: Use of Target Costing

\begin{tabular}{|l|l|l|}
\hline Use of Target Costing & N (Number) & Percentage (\%) \\
\hline & & \\
\hline Do not implement target costing & 2 & 14.3 \\
\hline Implement target costing & 8 & 57.1 \\
\hline Plan to implement in the future & 4 & 28.6 \\
\hline
\end{tabular}

When asked if they implement the method of target costing at their enterprises, $14.3 \%$ of the respondents said they did not implement it, $57.1 \%$ implemented it, and $28.6 \%$ planned to implement in the future. This breakdown reveals that target costing is implemented in the furniture industry, and those enterprises without 
any implementation of target costing could plan implementation in the future. Enterprises not implementing target costing were inquired as to why they did not implement it, and the following results were obtained. Lack of sufficient knowledge on target costing was observed to be the key reason for not implementing the method. The second important reason was "failure to get support from the senior management", while the third reason was "lack of cross-functional cooperation". In an attempt to determine the success of target costing, respondents were asked the extent to which they agreed with the following statements as a result of target costing, if they implemented it.

Table 14: The Success of Target Costing

\begin{tabular}{|l|l|l|l|l|l|l|l|l|l|l|}
\hline Factors & \multicolumn{2}{l}{$\begin{array}{l}\text { Strongly } \\
\text { Agree }\end{array}$} & \multicolumn{2}{l}{ Agree } & \multicolumn{2}{l}{ Not Certain } & \multicolumn{2}{l|}{ Disagree } & \multicolumn{2}{l|}{$\begin{array}{l}\text { Strongly } \\
\text { Disagree }\end{array}$} \\
\cline { 2 - 11 } & $\mathrm{N}$ & $\%$ & $\mathrm{~N}$ & $\%$ & $\mathrm{~N}$ & $\%$ & $\mathrm{~N}$ & $\%$ & $\mathrm{~N}$ & $\%$ \\
\hline $\begin{array}{l}\text { New product costs } \\
\text { dropped before } \\
\text { production. }\end{array}$ & 3 & 21.4 & 5 & 35.7 & 0 & 0 & 0 & 0 & 0 & 0 \\
\hline $\begin{array}{l}\text { Customer expectations } \\
\text { for our products } \\
\text { fulfilled }\end{array}$ & 6 & 42.9 & 2 & 14.3 & 0 & 0 & 0 & 0 & 0 & 0 \\
\hline $\begin{array}{l}\text { Production costs } \\
\text { dropped }\end{array}$ & 2 & 14.3 & 5 & 35.7 & 1 & 7.1 & 0 & 0 & 0 & 0 \\
\hline $\begin{array}{l}\text { Total profitability } \\
\text { increased }\end{array}$ & 0 & 0 & 8 & 57.1 & 0 & 0 & 0 & 0 & 0 & 0 \\
\hline $\begin{array}{l}\text { Costs of raw materials, } \\
\text { materials, parts and } \\
\text { components } \\
\text { procured by suppliers } \\
\text { dropped }\end{array}$ & 1 & 7.1 & 4 & 28.6 & 3 & 21.4 & 0 & 0 & 0 & 0 \\
\hline $\begin{array}{l}\text { Providing product } \\
\text { features and functions } \\
\text { expected by customers } \\
\text { became easier }\end{array}$ & 0 & 0 & 6 & 42.9 & 2 & 14.3 & 0 & 0 & 0 & 0 \\
\hline $\begin{array}{l}\text { Number of changes to } \\
\text { design required after } \\
\text { production dropped }\end{array}$ & 0 & 0 & 2 & 14.3 & 5 & 35.7 & 1 & 7.1 & 0 & 0 \\
\hline $\begin{array}{l}\text { Cross-functional } \\
\text { cooperation improved }\end{array}$ & 0 & 0 & 5 & 35.7 & 3 & 21.4 & 0 & 0 & 0 & 0 \\
\hline $\begin{array}{l}\text { Wholesalers' and } \\
\text { retailers' impact on } \\
\text { design grew }\end{array}$ & 3 & 21.4 & 3 & 21.4 & 2 & 14.3 & 0 & 0 & 0 & 0 \\
\hline
\end{tabular}

$35.7 \%$ of the respondents agreed and $21.4 \%$ strongly agreed new product costs dropped before production. $42.9 \%$ said they strongly agreed and $14.3 \%$ agreed customer expectations for products were fulfilled. $35.7 \%$ of the enterprises agreed production costs dropped. $57.1 \%$ agreed total profitability increased, while $28.6 \%$ said they agreed costs of raw materials, materials, parts and components from suppliers dropped. $42.9 \%$ agreed providing product features and functions expected by customers became easier, whereas $14.3 \%$ said they were uncertain with this statement. "Number of changes to design required after production dropped" garnered $14.3 \%$ "agree" replies and 35.7\% "not certain" replies. 35.7\% agreed cross-functional cooperation increased, whereas $21.4 \%$ said they were not certain. $21.4 \%$ strongly agreed, $21.4 \%$ agreed and $14.3 \%$ said they were uncertain with the fact that wholesalers' and retailers' impact on design grew.

\section{CONCLUSION AND SUGGESTIONS}

Target costing helps determine the cost by subtracting the desired profit margin from the market price set according to market research results. Applied throughout the design stage of a product, target costing primarily addresses the issue of closing the gap between the target cost and the cost enterprises attain with 
their own means. A significant portion of costs can be determined in design stage; therefore, cost reduction efforts should be undertaken in design to close this gap, by taking customer requirements and needs into account and not compromising on quality. This study involves a survey of 14 enterprises registered at the Turkish Furniture Industrialists' Association to determine whether target costing is implemented and its principles are followed by enterprises even if they do not implement the method.

Enterprises should pay attention to quality, speed, timing, and first and foremost, costs, considering the fact that they operate in highly competitive environments. Enterprises point to costs as the most important factor in achieving competitive advantage. That is why they should place emphasis on cost reduction efforts, for which target costing is deemed feasible. Besides costs, quality and design seem to have an impact on enterprises' competitiveness. Design was stated as the most important leverage in competition after cost and quality. More attention should be paid to design, since customer requests shape the furniture industry.

Enterprises are observed to find out customer expectations through regular market research and feedback from suppliers and retailers during product design. This increases the level of target costing implementation. In target costing, customer expectations should be identified especially before product design and market research covering suppliers and retailers should be conducted in design phase. For enterprises to implement target costing, they need the assistance of other stakeholders within the value chain. Enterprises who participated in the survey could be said that they partially got assistance from those stakeholders. However, engagement and involvement of the members within the value chain should be enhanced. To achieve effectiveness, enterprises should leverage more on design and production engineering departments, which correspond to the most important part of target costing. This means that a broad participation and engagement with internal and external parties is required for enterprises to reach the target cost.

Majority of the enterprises in the furniture industry are observed to be employing traditional cost management systems in setting the selling price. Enterprises should leave traditional methods behind and opt for the methods of target costing including market research to provide products at the selling price that is desired by the customers.

Respondents were observed to have knowledge on target costing, with the majority of them implementing the method. They, however, applied only the key principles required by the implementation of target costing. Enterprises not implementing the method expressed their willingness to do so in the future. This serves as significant data showing that target costing will be more frequently used in the future. For enterprises not implementing the method, target costing could be successfully implemented once a certain understanding of the method is acquired, support from the senior management is guaranteed and cross-functional cooperation is increased.

Enterprises implementing the method could be said to implement it properly. However, the method will prove more successful if the following principles are followed in a more careful and controlled manner:

1. Taking the price desired by customers and set by the market into account while determining the selling price of a new product;

2. Making cost estimates during design and before production, and undertaking cost reduction efforts throughout the entire product life-cycle;

3. Identifying customer expectations at the design phase through regular market research; and

4. Including internal and external stakeholders of the value chain in the method.

As a conclusion, majority of the enterprises implementing target costing stated it helped address customer requirements and reduce costs. They will be able to utilize the method as a significant tool for competitive advantage if they follow aforementioned principles more diligently. Enterprises not implementing it, on the other hand, are observed to be internally following the principles of the method in general terms. Its implementation will be successful if the senior management assumes an active role for its organization-wide ownership. 


\section{REFERENCES}

Altınbay, A. (2006). Etkin Bir Maliyet Yönetimi Olarak Hedef Maliyetleme Sistemi ve TMMT Uygulaması. Dumlupinar Üniversitesi Sosyal Bilimler Dergisi, Vol.16, 141-164.

Ansari, S. \& Bell, J. (1997).Target Costing: The Next Frontier in Strategic Cost Management, Irwin Professional Publishing, Chicago.

Baharudin, N. \& Jusoh, R. (2015). Target Cost Management (TCM): A Case Study of an Automotive Company. Procedia - Social and Behavioral Sciences.

Bahşi, G. \& Can, V. (2001). Hedef Maliyetleme, Muhasebe ve Denetime Bakış, 4. May

Bozdemir, E. \& Orhan, S. (2011). Maliyet Kontrol Aracı Olarak Hedef Maliyetleme Yönteminin Türk Otomotiv Sanayinde Uygulanabilirlik Düzeyinin İncelenmesi. Atatürk Üniversitesi İktisadi ve İdari Bilimler Fakültesi Dergisi, 25(2), 163-179.

Can, A.V. (2004). Hedef Maliyetleme. Sakarya Kitabevi, Sakarya.

Castellano, J. F. \& Young, S. (2003). Speed Splasher: An Interactive, Time-Based Target Costing Exercise. Journal Of Accounting Education, Vol: 21, 149-155.

CFI, 2019. https://corporatefinanceinstitute.com/resources/knowledge/accounting/target-costing/

Cooper, R. (1994). Japanese Cost Management Practices. CMA Magazine, 10, $20-25$.

Cooper, R. \& Slagmulder, R. (1997). Target Costing and Value Engineering. Portland, Oregon: Productivity Press, Oregon.

Coşkun, A. (2002-2003). Stratejik Maliyet Yönetimi Aracı Olarak Hedef Maliyetleme. Akademik Araştırmalar Dergisi, 4(15), 25-34.

Dekker, H. \& Smidt, P. (2003). A Survey on The Adoption of Use of Target Costing in Dutch Firms, International Journal of Production Economics, 84, 293-305.

Dimi, O. \& Simona, B. S. (2014). Target Costing-the Response of The Managerial Accounting to Changes in The Environment. Annals-Economy Series, Vol.3, 45-55.

Everaert, P.; Loosveld, S.; Tom, S. \& Sarens, G. (2006). Characteristics of Target Costing: Theoretical and Field Study Perspective. Qualitative Research in Accounting \& Management, 3(3).

Hacırüstemoğlu, R.; Şakrak, M. (2002). Maliyet ve Yönetim Muhasebesinde Güncel Yaklaşımlar, Türkmen Kitabevi.

Hansen, D. \& Mowen, M. (1999). Cost Management: Accounting and Control. South-Western College Publishing, 554-569.

Helms, M. M.; Ettkin, L. P.; Baxter, J. T., \& Gordon, M. W. (2005). Managerial Implications of Target Costing. Competitiveness Review: An International Business Journal, 15(1), 49-56.

Kalkancı, N. (2008). Hedef Maliyetleme Sisteminde Bütçe Yaklaşımı, Yöneticilerin Eğitimi ve Bir İşletmede Uygulama, Yayımlanmamış Yüksek Lisans Tezi, Gazi Üniversitesi Eğitim Bilimleri Enstitüsü, Ankara.

Kaplan, R. S.; Atkinson, A. A. (1998). Advanced Management Accounting, Third Edition,New Jersey: Prentice Hall Int,Inc.

Karcıoğlu, R. (2000). Stratejik Maliyet Yönetimi, Maliyet ve Yönetim Muhasebesinde Yeni Yaklaşımlar. Erzurum: Aktif Yayınevi.

Kato, Y. (1993). Target Costing Support Systems: Lessons from Leading Japanese Companies, Management Accounting Research, 4, 33-47.

Kaygusuz, S.Y. \& Dokur, Ş. (2015). Yönetim Muhasebesi. Dora Basım Yayın Dağıtım.

Lorino, P. (1995). Target Costing Practices and Implementation. International Federation of Accountants: Articles of Merit. 
D. Celayir 12/2 (2020) 1308-1321

Ramanan R. (2000). Target Costing. In: Swamidass P.M. (ed.) Encyclopedia of Production and Manufacturing Management. Springer, Boston.

Sakurai, M. (1989). Target costing and how to use it, Journal of Cost Management, 39-50.

Sakurai, M. (1990). Target Costing and How to use It. Emerging Practise in Cost Management, (Ed. Barry J. Brinker) Warren, Grham\&Lamont Inc., Boston.

Sakurai, M. (1996). Integrated Cost Management: A Companywide Prescription for Higher Profits, Portland, Oregon, Productivity Press.

Schmelze, G.; Geiger, R. (1996). Target Costing at ITT Automotive, Management Accounting, December.

Seidenschwarz,W. (1993). Target Costing Marktorientiertes Zielkostenmanagement. München: Vahlen.

Swenson, D.; Ansari, S.; Bell, J. \& Kim, I. (2003). Best Practices in Target Costing. Management Accounting Quarterly, 4, 12-17.

Tanaka, M. (1997). The Present State of Target Costing in Japanese Enterprises. Accounting, 49(8).

Taylor, T.C. (2000). Current Developments In Cost Accounting And The Dynamics Of Economic Calculation. The Quarterly Journal of Austrian Economics, 3(2), 3-19.

Yalçın, S. (2005). Müşteri Odaklı Yeni Ürün Geliştirme Aracı Olarak Hedef Maliyetleme ve Kalite Fonksiyon Yayılımının Mobilya Sektöründe Uygulanabilirliğinin Analizi, Dumlupınar Üniversitesi Doktora Tezi.

Yükçü, S. (1999). Yeni Bir Fiyatlandırma Yaklaşımı Olarak: Hedef Maliyetleme. Muhasebe Bilim Dünyası Dergisi, $1(3)$. 